Japan. J. Med. Sci. Biol., 29, 215-219, 1976

\title{
EFFECT OF CYCLOHEXIMIDE ON THE REPLICATION OF WESTERN EQUINE ENCEPHALITIS VIRUS
}

In alpha-togavirus replication, two principal forms of single-stranded RNA are found; one is infectious 42S RNA identical with virion RNA and the other 26S RNA regarded as messengers for structural proteins. The virus-specific RNA polymerase activity is induced in the infected cells and the course of appearance of the enzyme activity generally parallels the course of viral RNA synthesis (Martin and Sonnabend, 1967; Takehara, 1971).

It was reported that the synthesis of infectious (virion) RNA in the cells infected with an alphavirus, western equine encephalitis (WEE) virus was inhibited by an inhibitor of protein synthesis, suggesting the lability of some enzyme involved in viral RNA synthesis (Sreevalsan and Lockart, 1964). On the contrary, the accumulating evidence has suggested that viral RNA synthesis does not require concomitant protein synthesis in closely related Sindbis or Semliki Forest virus replication (Scheele and Pfefferkorn, 1969; Friedman and Grimley, 1969; Waite, 1973). We, therefore, re-investigated the interrelationship of viral RNA and protein synthesis in the cells infected with WEE virus. Our results suggest that WEE virus RNA synthesis, once it has reached its maximal rate, does not require concomitant protein synthesis.

WEE virus propagated in primary chick embryo (CE) cells as described previously (Hashimoto, Suzuki and Simizu, 1975) were used to infect monolayer cultures of BHK cells grown on 35-mm plastic dishes. Cultures were pretreated with $1 \mu \mathrm{g}$ of actinomycin $\mathrm{D}$ per $\mathrm{ml}$ for $1 \mathrm{hr}$ and then infected with WEE virus at $10 \mathrm{PFU}$ per cell. At various times after infection, the infected cultures were added with cycloheximide (CH; Wako Pure Chemical Ind., Osaka) to $10 \mu \mathrm{g} / \mathrm{ml}$, at which concentration of the drug protein synthesis in the cells was inhibited by more than $90 \%$ (data not shown). Then the cells were labeled with $\left[{ }^{3} \mathrm{H}\right]$ uridine (25 Ci/mmole, Radiochemical Centre, Amersham) at indicated intervals and solubilized with SDS ( $1 \%$ in final) at the end of the labeling period. For analysis of RNA, the cell extract was sedimented through SDS-sucrose gradient as described elsewhere (Hashimoto et al., 1975).

First, we tested the effect of $\mathbf{C H}$ on subsequent virus production. At various times after infection, one set of duplicate cultures was harvested and $10 \mu \mathrm{g} / \mathrm{ml}$ of $\mathrm{CH}$ was added to another set of duplicate cultures. All $\mathrm{CH}$-treated cultures were harvested at $8 \mathrm{hr}$ post-infection (p.i.) together with the last set of cultures in the untreated series. Virus titers of the culture fluids were determined by 
plaque assay on CE cells. Figure 1 shows no increase in virus yield after addition of $\mathrm{CH}$, indicating that $\mathrm{CH}$ inhibits the subsequent virus production.

Second, we investigated the requirement of protein synthesis to initiate and maintain the synthesis of viral RNA. Actinomycin D-treated cells were infected and exposed to $\mathrm{CH}(10 \mu \mathrm{g} / \mathrm{ml})$ at various times after infection. The rate of viral RNA synthesis was measured by the incorporation of $\left[{ }^{3} \mathrm{H}\right]$ uridine added simultaneously with $\mathrm{CH}$. Block of protein synthesis immediately after infection almost completely inhibited subsequent viral RNA synthesis (Fig. 2a,b). This suggests that new protein synthesis required at an early stage $(0-2 \mathrm{hr})$ of infection to initiate and maintain the normal rate of viral RNA synthesis. The rate of viral RNA synthesis in the cells treated with $\mathrm{CH}$ at $2 \mathrm{hr}$ p.i. was inhibited to some extent, probably due to insufficiency of viral RNA polymerase synthesized during the first $2 \mathrm{hr}$ of infection (Fig. 2c). On the other hand, addition of $\mathrm{CH}$ at $3 \mathrm{hr}$ p.i. or later had no inhibitory effect on the subsequent rate of RNA synthesis (Fig. 2d-f).

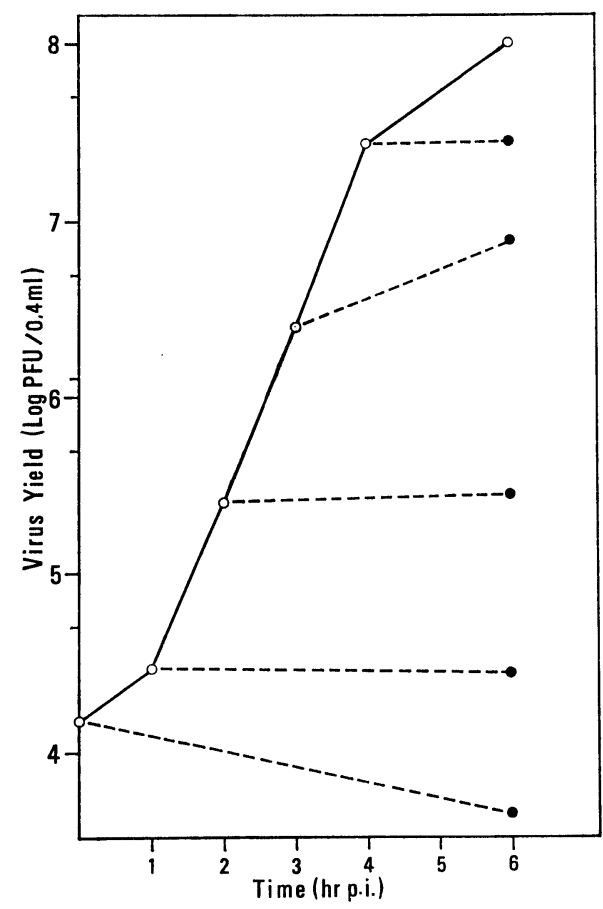

Fig. 1. Effect of $\mathrm{CH}$ on subsequent virus production. BHK cells (ca. $5 \times 10^{5}$ ) were infected with WEE virus at $10 \mathrm{PFU} /$ cell. At indicated times, the infected cultures were harvested and $\mathrm{CH}(10 \mu \mathrm{g} / \mathrm{ml})$ was added to replicate cultures. All of $\mathrm{CH}$-treated cultures were harvested at $8 \mathrm{hr}$ p.i. together with the last cultures in untreated series. Virus titers in the culture fluids were determined by plaque assay on CE cells. (O) cultures taken for assay at indicated time; (O), cultures added with $\mathrm{CH}$ at indicated time and incubated for $6 \mathrm{hr}$ after infection. 


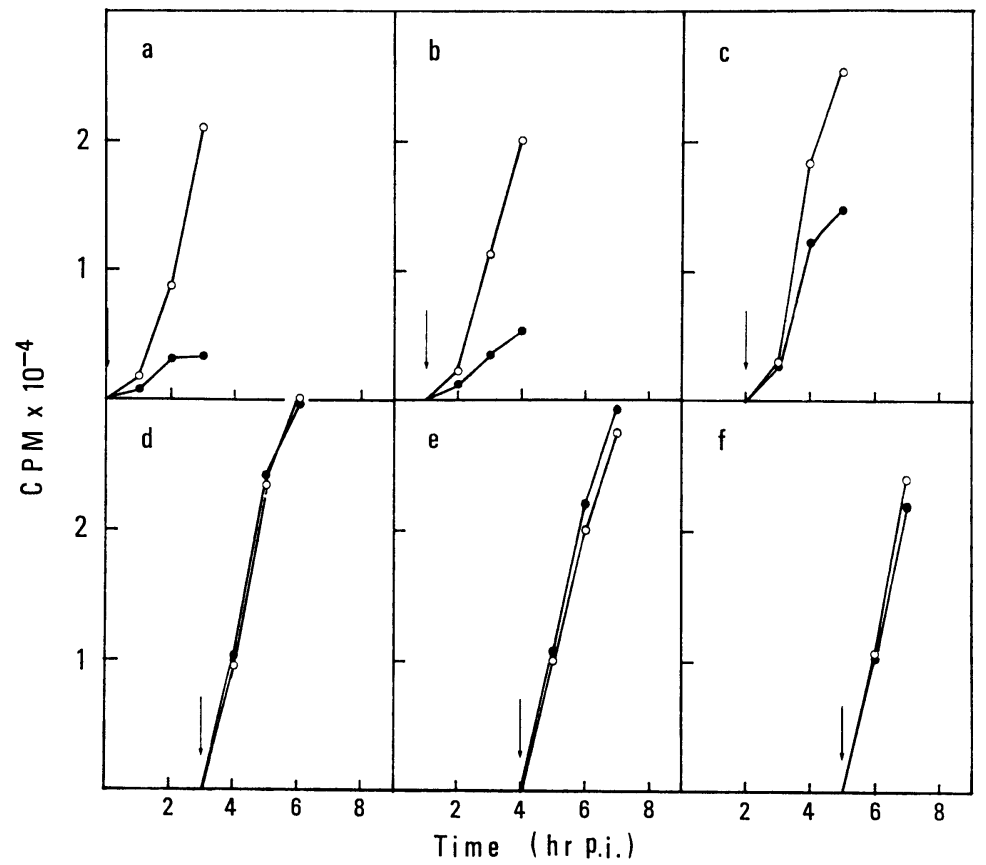

Fig. 2. Effect of $\mathbf{C H}$ on the synthesis of viral RNA. Actinomycin D-treated BHK cell cultures were infected with WEE virus. At indicated times (arrows), one-half of them was treated with $\mathrm{CH}$ at $10 \mu \mathrm{g} / \mathrm{ml}(\bullet)$, whereas the other half served as control (O). Drugtreated and control cultures were labeled with $\left[{ }^{3} \mathrm{H}\right]$ uridine $(5 \mu \mathrm{Ci} / \mathrm{ml})$ from the indicated times and removed at specified intervals for determination of labeled RNA.

Finally, the nature of viral RNA formed in the presence of $\mathrm{CH}$ was analyzed by velocity sedimentation. Figure 3 shows that no significant viral RNA species is evident in the cells treated with $\mathrm{CH}$ immediately after infection, whereas all of the species of viral RNA present in the control cells appear when added with $\mathrm{CH}$ at $2 \mathrm{hr}$ p.i. or later. The amounts of total viral RNA in the cells treated at $2 \mathrm{hr}$ p.i. are about $30 \%$ less than those of control and both $42 \mathrm{~S}$ and $26 \mathrm{~S}$ RNA are inhibited at similar rates. In contrast, the amounts of both RNA species present in the cells treated with $\mathrm{CH}$ at $3 \mathrm{hr}$ p.i. are slightly larger than those of control. This may be due to an intracellular accumulation of viral RNA in CH-treated cells because of the defect of viral assembly.

Our results suggest that new protein synthesis at an early stage of infection is required for subsequent viral RNA synthesis, while at a later stage of infection, WEE virus RNA is synthesized normally without concomitant protein synthesis. This is in agreement with the observation for Sindbis and Semliki Forest Viruses (Scheele and Pfefferkorn, 1969; Friedman and Grimley, 1969). Since the viron RNA of alphavirus is infectious and no polymerase activity is found in the virion (Baltimore, Huang and Stampfer, 1970), the parental virion 


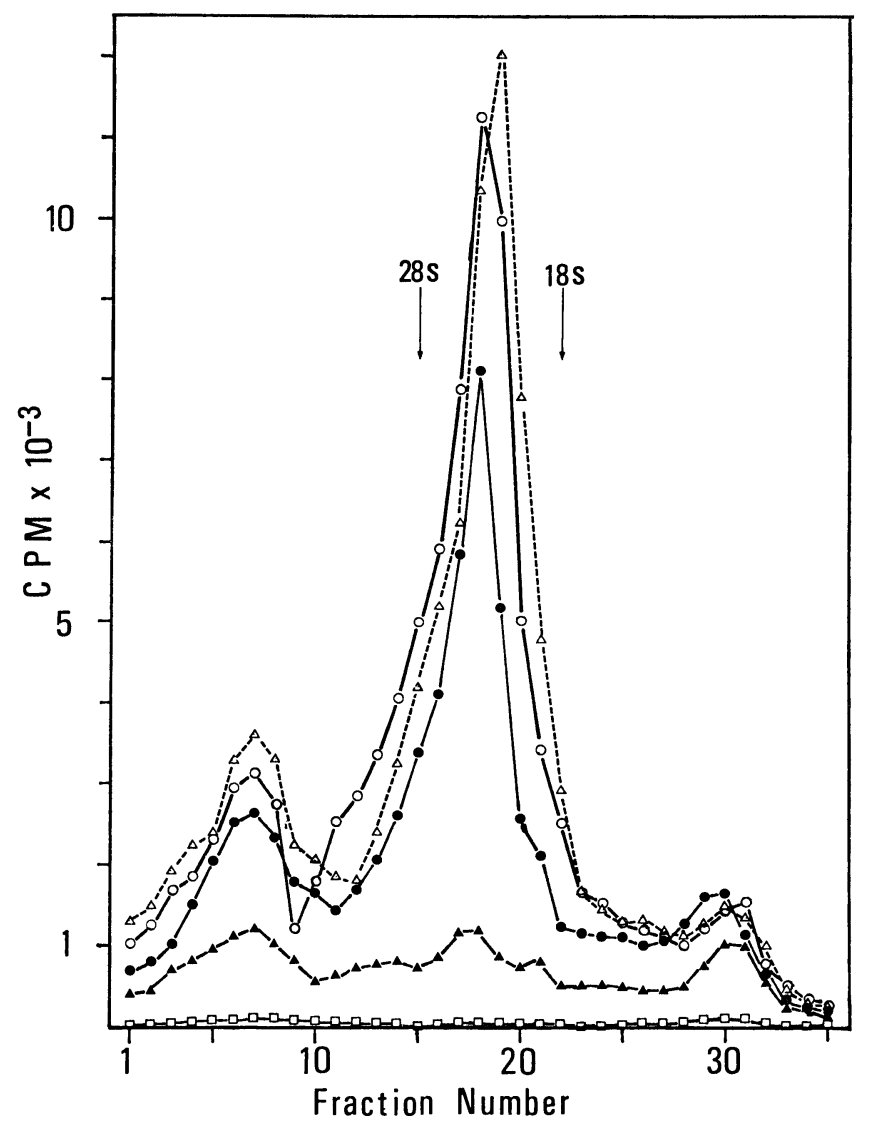

Fig. 3. Sedimentation profiles of viral RNA synthesized in CH-treated cells. Cells were infected and treated with $\mathrm{CH}(10 \mu \mathrm{g} / \mathrm{ml})$ at indicated times. At $4 \mathrm{hr}$ p.i., the cells were labeled with $\left[{ }^{3} \mathrm{H}\right]$ uridine $(10 \mu \mathrm{Ci} / \mathrm{ml})$ for $1 \mathrm{hr}$ and then solubilized with $1 \%$ SDS. The cell extract was layered on 15 to $30 \%$ SDS-sucrose gradient and centrifuged in a Spinco SW27 rotor at $24,000 \mathrm{rpm}$ for $15 \mathrm{hr}$ at $20 \mathrm{C}$. Fractions of $1 \mathrm{ml}$ were collected and determined for TCA-insoluble radioactivity. Sedimentation was from right to left. Symbols; Control (O), CH-treated at $0(\square), 1(\Delta), 2(\bullet)$ and $3 \mathrm{hr}(\Delta)$ after infection.

RNA may first serve as a messenger for some enzyme(s) involved in viral RNA synthesis at an early stage of infection. The step can be inhibited by an inhibitor of protein synthesis. Independence of late viral RNA synthesis from concurrent protein synthesis suggests that alphavirus RNA polymerase(s) formed at an early stage of infection may be so stable that viral RNA can be synthesized by the preformed enzymes at a later stage of infection. The stability of the enzyme is also suggested by the evidence that temperature-sensitive mutants of Sindbis or Semliki Forest virus defective in viral RNA synthesis could synthesize viral RNA in the cultures shifted to a restrictive temperature (Pfefferkorn and Burge, 1967; Tan, Sambrook and Bellett, 1969; Martin, 1969). 


\section{REFERENCES}

Baltimore, D., Huang, A. S. AND Stampfer, M. (1970): Ribonucleic acid synthesis of vesicular stomatitis virus. II. An RNA polymerase in virion. Proc. Nat. Acad. Sci., 66, 572-576.

Friedman, R. M. AND Grimley, P. M. (1969): Inhibition of arbovirus assembly by cycloheximide. J. Virol., 4, 292-299.

Hashimoto, K., Suzuki, K. AND Simizu, B. (1975): Morphological and physical properties of a multiploid-forming mutant of western equine encephalitis virus. J. Virol., 15, 1454-1466.

Martin, E. M. And Sonnabend, J. A. (1967): Ribonucleic acid polymerase catalyzing synthesis of double-stranded arbovirus ribonucleic acid. J. Virol., 1, 97-109.

Martin, E. M. (1969): Studies on the RNA polymerase of some temperature-sensitive mutants of Semliki Forest virus. Virology, 39, 107-117.

Pfefferkorn, E. R. ANd Burge, B. W. (1967): The Molecular Biology of Viruses (J. Colter ed.). p. 403-426. Academic Press, New York.

Scheele, C. M. AND Pfefferkorn, E. R. (1969): Inhibition of interjacent ribonucleic acid (26S) synthesis in cells infected by Sindbis virus. J. Virol., 4, 117-122.

SREevalsan, T. ANd LockarT, J. R. Z. (1964): Inhibition by puromycin of the initiation of synthesis of infectious RNA and virus by chicken embryo cells infected with western equine encephalomyelitis virus. Virology, 24, 91-96.

TAkehara, M. (1971): Comparative studies on nucleic acid synthesis and virus-induced RNA polymerase activity in mammalian cells infected with certain arboviruses. Arch. Ges. Virusforsch., 34, 266-277.

Tan, K. B., Sambrook, J. F. ANd Bellett, A. J. D. (1969): Semliki Forest virus temperaturesensitive mutants: isolation and characterization. Virology, 38, 427-439.

Waite, M. R. F. (1973): Protein synthesis directed by an RNA- temperature-sensitive mutant of Sindbis virus. J. Virol., 11, 198-206.

Department of Virology and Rickettsiology,

National Institute of Health,

Kamiosaki, Shinagawa-ku, Tokyo 141,
KATSUYUKI HASHIMOTO BUNSITI SIMIZU

(Received: May 8, 1976)

橋本雄之・清水文七（国立予防衛生研究所 ウイルスリケッチャ部） 